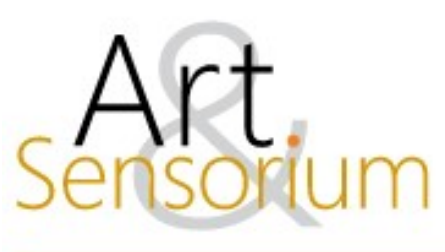

\title{
JOKER: ANÁLISE FÍLMICA SEGUNDO O DESPERTENCIMENTO SOCIAL
}

\author{
DOI: https://doi.org/10.33871/23580437.2020.7.2.082-100
}

Antenor Ferreira Correa ${ }^{1}$

\begin{abstract}
Resumo: neste artigo, apresenta-se uma análise do filme Joker (2019) de Todd Phillips. O filme é compreendido no gênero estudo de personagem e aqui considerado sob a contínua frustração de expectativas na narrativa fílmica operadas pelo comportamento do personagem principal, bem como do seu insucesso em estabelecer conexões de modo a lograr um sentimento de pertencimento. Essas características, a simbologia desvelada e os argumentos da análise aqui proposta serão apoiadas por conteúdos presentes no roteiro, na música original, na expressão corporal, intertextualidades e ilustradas por elementos cinematográficos. Espera-se com esse exercício hermenêutico desvendar camadas de significação veladas no roteiro e não apreensíveis em uma observação passiva do filme.
\end{abstract}

Palavras-chave: Joker; despertencimento social; quebra de expectativas; estudo de personagem.

\section{JOKER: A FILM ANALYSIS ACCORDING TO SOCIAL NON-BELONGINGNESS}

Abstract: this article presents an analysis of Todd Phillips's Joker (2019). The film is comprehended as a "character study" genre and considered under the continuous frustration of expectations in the narrative operated by the main character's behavior, as well as his failure to establish connections in order to achieve a feeling of belonging. These characteristics, the symbology unveiled and the arguments for the analysis here proposed will be supported by contents present in the script, underscore music, body expression, intertextualities, and illustrated by cinematographic elements. This hermeneutic exercise is aimed to reveal some layers of significance present in the plot but not easily apprehensible in a passive observation of the film.

Keywords: Joker, social not belonging, smash of expectations, character study.

\section{JOKER: UN ANÁLISIS CINEMATOGRÁFICO SEGÚN LA NO PERTENENCIA SOCIAL}

Resumen: este artículo presenta un análisis del Joker de Todd Phillips (2019). La película se comprende en lo género "estudio de personajes" y se considera bajo la continua frustración de las expectativas en la narrativa operada por el comportamiento del personaje principal, así como su fracaso para establecer conexiones con el fin de lograr un sentimiento de pertenencia. Estas características, la simbología revelada y los argumentos del análisis propuesto serán respaldados por los contenidos presentes en el guión, la música original, la expresión corporal, intertextualidad y se

\footnotetext{
${ }^{1}$ Compositor, arranjador e percussionista. Professor associado da Universidade de Brasília. Possui pós-doutorado pela Universidad de Granada (Espanha) e pela University of California, Riverside (EUA). É doutor em composição musical pela Universidade de São Paulo (USP). Editor do livro Music, Speech, and Mind (ABCM, 2019). Atualmente coordena o MediaLab, Laboratório em Arte Computacional da UnB, vinculado ao Programa de Pós-Graduação em Artes Visuais da Universidade de Brasília. https://orcid.org/0000-0003-0257-3059.antenorferreira@yahoo.com.br
} 
ilustran con elementos cinematográficos. Este ejercicio hermenéutico tiene como objetivo revelar algunas capas de significación presentes en la trama pero no fácilmente perceptibles en una observación pasiva de la película.

Palabras clave: Joker, no pertenencia social, quiebra de expectativas, estudio de personaje.

\section{Introdução}

Unsuitable é uma palavra da língua inglesa que traz algumas acepções imediatas para os familiarizados com esse idioma, como por exemplo, inadequado, incompatível, inoportuno, inconveniente e impróprio. É fácil notar que se trata de uma palavra composta de un+suit+able e o prefixo un é partícula negativa. Suit, assim, é o radical da palavra e funciona como substantivo, adjetivo e, também, como verbos compostos (phrasal verbs). No entanto, o que talvez poucos se lembrem é que suit possui ainda outro significado: é o coletivo que agrupa as cartas do baralho, ou seja, os respectivos naipes.

Em português nomeamos os naipes como ouros, espadas, copas e paus ${ }^{2}$. Um baralho padrão possui 52 cartas que se dividem em 13 classes (Ás, 2, 3, 4, 5, 6, 7, 8, 9, 10, J, Q, K) reunidas nos 4 naipes (suits). Pergunta: qual o naipe do coringa (Joker)? Resposta: o coringa não possui naipe, é uma carta singular, ou seja, unsuitable. Entretanto, ao mesmo tempo o coringa pode, em certos jogos, adequarse de modo a substituir qualquer outra carta e funcionar como trunfo, isto é, a carta de maior valor. Em diversos jogos, o coringa funciona como uma wild card, uma carta que pode substituir qualquer outra carta escolhida pelo jogador ${ }^{3}$. Curiosamente, wild card é também a maneira de se referir a uma pessoa cujo comportamento não pode ser previsto, ou seja, uma pessoa imprevisível. Esses dois aspectos, imprevisibilidade e singularidade, do coringa serão utilizados como guias para a análise aqui proposta do filme Joker (2019, Warner Bros Pictures).

Joker foi produzido e dirigido por Todd Phillips que também escreveu o roteiro em parceria com Scott Silver. Joker é o personagem das histórias em quadrinhos da editora norte-americana D.C. Comics que se constituiu como o mais longevo inimigo do herói Batman. O filme é ambientado na fictícia Gotham City que, por sua vez, representa Nova Iorque em $1981^{4}$, quando os coletores de lixo entraram em greve e o lixo se acumulou assustadoramente pela cidade. O personagem Joker (interpretado por Joaquin Phoenix, vencedor do Oscar por essa atuação) é apresentado nessa história como possuidor de uma doença nervosa tecnicamente denominada "labilidade emocional". Essa condição faz com que a pessoa apresente reações involuntárias e descontroladas em situações de stress, nervosismo ou desconforto. O personagem não tem, portanto, domínio sobre sua risada, levando os outros a perceberem-no como um doente mental.

Tecnicamente, o filme Joker constitui-se como um estudo de personagem (character study) ${ }^{5}$, ou seja, um gênero no qual um personagem possui primazia sobre a ação e, por conta disso, busca-se uma compreensão detalhada do caráter, da personalidade, da profundidade psicológica e moral que levam a determinados comportamentos, enfim, uma descrição densa da personagem. Uma das definições mais utilizadas de estudo de personagem é: o tipo de filme no qual "o delineamento do personagem

\footnotetext{
${ }^{2}$ As designações dos naipes em inglês e francês, respectivamente, são: diamonds, carreaux; spades, piques; hearts, coeurs; clubs, trefles. Em português, os nomes dos naipes foram também misturados com o espanhol: oros, espadas, copas (que significa cálice) e bastos (ou seja, bastões ou paus).

${ }^{3}$ A adição do Joker ao baralho ocorreu nos Estados Unidos em cerca de 1860, não havendo indicação dessa carta no baralho europeu. Uma variação do pôquer em 1875 é o primeiro registro histórico do uso do Joker, justamente, como wild card. Fonte: https://playingcarddecks.com . Acessado em 25/03/2020.

${ }^{4}$ Outro dado confirmando essa data é a cena mostrando o filme Zorro: The Gay Blade, em cartaz nos cinemas americanos justamente no ano de 1981.

${ }^{5}$ Importante entrevista com o diretor Todd Phillips na qual, entre vários aspectos, ele descreve como idealizou esse estudo de personagem: https://www.youtube.com/watch?v= Hf_yGDPCUg
} 
central é mais importante que o enredo"6. São exemplos de estudo de caráter filmes como Taxi Driver (de Martin Scorsese), Cidadão Kane (de Orson Welles), Andrei Rublev (de Andrei Tarkovsky) e Morangos Silvestres (de Ingmar Bergman). Neste sentido, Joker será aqui considerado sob a contínua frustração de expectativas na narrativa fílmica operadas pelo comportamento do personagem principal e sob o aspecto do insucesso dessa personagem em estabelecer conexões de modo a lograr um sentimento de pertencimento. Essas características, a simbologia desvelada e os argumentos da análise aqui proposta serão apoiadas por conteúdos presentes no roteiro e ilustradas por elementos cinematográficos. O fundamento teórico, por sua vez, faz uso do conceito de "despertencimento" como entendido pela psicologia social. Nesse sentido, dialoga, sobretudo, com pesquisadores e estudiosos da área de estresse pós-traumático.

Espera-se com esse exercício hermenêutico desvendar algumas camadas de significação presentes no filme. Espera-se, também, diminuir o preconceito observado para com alguns filmes que por serem classificados como comerciais ou mera peças de entretenimento são desconsiderados por pesquisadores. Há posicionamentos extremados com relação à cultura de massa, de modo geral, e, especialmente, contra a Academia de Hollywood. Pessoalmente, não tenho qualquer apreço por essa instituição em si; porém, é inegável a influência que a mesma possui sobre a população mundial. Para o âmbito específico deste artigo, penso que rotulações apressadas muitas vezes acabam por relegar certas obras a um nicho de indiferença ou irrelevância e, assim, aspectos e potencialidades interessantes das mesmas acabam desconhecidos. Esse é o caso de Joker que se vale de um personagem e de uma cidade fictícia para discutir problemas reais e atuais. Espero que a análise aqui proposta possa colocar em evidência elementos fílmicos e informações de interesse para os leitores e apreciadores da chamada sétima arte.

\section{Roteiro: Everything Must Go}

No início do filme, Arthur Fleck (nome do Joker) maquia-se em frente ao espelho e move seus lábios de modo a imitar as máscaras da comédia e da tragédia. O gesto de fazer o sorriso é feito com suas mãos, com muita intensidade e de modo quase agressivo. Quando ele segura seus lábios na posição de comédia, a tinta da maquiagem escorre de um de seus olhos como se fosse uma lágrima. Esse gesto é a primeira pista da transformação levada à cabo no processo de busca, ou aceitação, de sua identidade. Ou seja, a conformidade com o fato de que se ele quiser sorrir terá que admitir o seu lado trágico, e esse processo será doloroso (Figura 1).
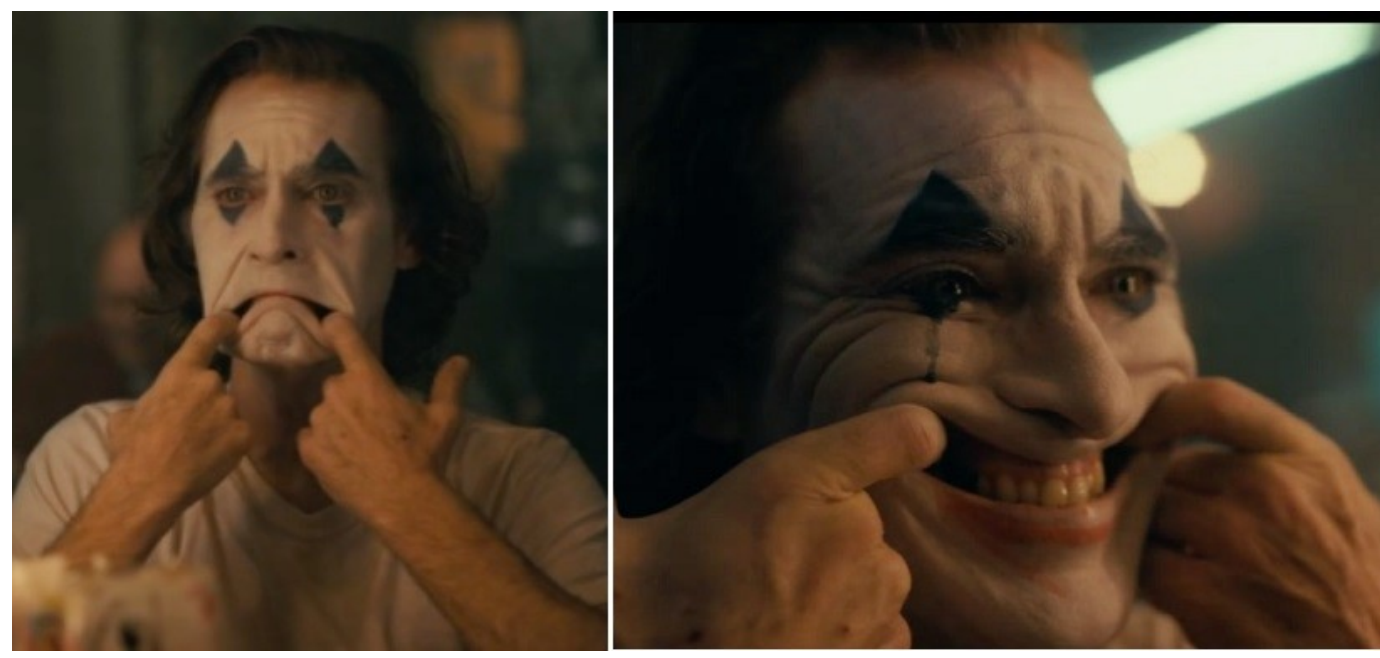

Figura 1: Arthur Fleck força um sorriso com as mãos representando as máscaras da tragédia e da comédia.

${ }^{6}$ Fonte: Internet Movie Data Base (IMDb) disponível em: https://www.imdb.com/list/ls040188319/

R. Inter. Interdisc. Art\&Sensorium, Curitiba, v.7, n.2, p. 082 - 100 Jul.- Dez. 2020 
O nome escolhido pelo diretor Todd Phillips é sugestivo e também adiciona outra camada de significado ao personagem. Fleck no inglês significa mancha, nódoa e, assim, metaforicamente representa a mancha que as diversas instâncias do poder querem remover do tecido social. Uma referência imediata associada ao nome Arthur é do Rei Artur (King Arthur), famoso conjunto de romances medievais, também denominados de lendas arturianas, tornado famoso pelo escritor Geoffrey de Monmouth (cidade galesa) em sua Historia Regum Britanniae (Histórias dos Reis da Grã-Bretanha,1135-1138) $)^{7}$ na qual conta, entre outras, as aventuras do Rei Artur e seus cavaleiros da távola redonda. Essa compreensão, embora anacrônica, não é desprovida de evidência no filme e ajuda a entender o passado do personagem. Ao longo da história, Arthur Fleck irá descobrir dois fatos essenciais sobre seu passado. Primeiro, ao ler uma carta escrita por sua mãe, ele descobre que é filho do milionário Thomas Wayne (pai do garoto Bruce Wayne que, como sabido, virá a tornar-se o superherói Batman). Segundo, ao abordar Thomas Wayne, Arthur Fleck fica enraivecido ao ser informado que, na verdade, ele é filho adotivo e sua mãe é louca. Esse episódio é apenas mais um na longa cadeia de frustrações que irão ocorrer a Arthur Fleck. Tentando comprovar a afirmação de Wayne, Fleck vai até o hospício Arkham e descobre, ao ler a ficha de internação de sua mãe, que ele foi realmente adotado e que sua mãe sofre de psicose ilusória e transtorno de personalidade narcisista. Desse modo, fica estabelecido o desconhecimento sobre a ascendência de Arthur, implicando, portanto, na inexistência de laços com seu passado e, como se verá, o enredo seguirá com a ruptura dos elos no presente. Similarmente, a origem do nome do Rei Artur é incerta e tem sido debatida entre os historiadores e linguistas. "A etimologia mais aceita deriva do romano nomen gentile Artorius. Artorius, por sua vez, é também de etimologia obscura e contestada, mas possivelmente tem origem etrusca ou messapiana (idioma já extinto do sudoeste da Itália). O linguista Stephan Zimmer sugere que Artorius possivelmente teve uma origem celta, sendo uma latinização de um nome hipotético Artorījos ${ }^{8 "}$. Assim, se estabelece o paralelo entre a incerteza do passado de ambos os personagens. Arthur Fleck é uma pessoa cujo passado é desconhecido ou apagado e uma mancha a ser removida no presente.

A ascendência desconhecida de Joker é também confirmada em outros filmes da franquia Batman. Por exemplo, em The Dark Knight (2008, no Brasil intitulado Batman: o cavaleiro das trevas) dirigido por Christopher Nolan tendo Joker interpretado por Heath Ledger (vencedor do Oscar de melhor ator por esse papel), quando Joker é preso, o comissário de polícia James Gordon é perguntado sobre o que conseguiu apurar sobre o detido, ele responde "Nada! Sem correspondência de impressão digital, DNA ou registros dentários. A roupa é customizada, sem etiqueta, nada nos bolsos além de facas e fiapos. Sem nomes ou outros apelidos!"’. Constata-se, assim, que o ponto de interrogação pairando sobre o passado de Joker é intencional.

Outro aspecto relevante associado ao fictício Rei Artur é que ele tentou ser bom e justo para com os outros, mas foi traído por muitas das pessoas que amava. O reinado do Rei Artur termina depois que sua esposa e seu melhor cavaleiro têm um caso ${ }^{9}$, ou seja, com uma traição. Da mesma forma, Arthur Fleck tenta no início do filme fazer o bem às pessoas, sobretudo à sua mãe, porém ao longo do enredo, também irá se considerar traído não apenas por ela, mas pela sociedade como um todo. Como um comentário adicional sobre a conexão entre Arthur Fleck e o Rei Artur, este, como reza a lenda, foi o legítimo possuidor da espada mágica Excalibur. Ao final do filme Joker, em meio à rebelião que tomou conta de Gotham City, a família Wayne deixa a sala de cinema e caminha para um beco. Nessa saída, pode-se ver um cartaz de publicidade na parede do cinema divulgando justamente o filme Excalibur.

\footnotetext{
${ }^{7}$ A lenda arturiana é baseada na vida ficcional do rei Arthur da Grã-Bretanha, desenvolvida a partir de histórias da mitologia celta. (Fonte: https://www.britannica.com/topic/Arthurian-legend acessado em 25/03/2020).

${ }^{8}$ Fonte: https://www.britannica.com/topic/Arthurian-legend Acessado em 25/03/2020.

${ }^{9}$ Fonte: https://www.britannica.com/topic/Arthurian-legend acessado em 25/03/2020).
} 
Por fim, várias ideias para o roteiro de Joker foram retiradas das histórias em quadrinho do Batman. Por exemplo, a ideia de Joker tentar e fracassar na carreira de comediante vem de The Killing Joke (2008). Nesse cartoon, Batman busca em seu poderoso computador informações sobre Joker, mas não encontra nada (Figura 2). Dentre as várias discussões existenciais apresentadas nesse quadrinho, Joker diz "Se eu vou ter um passado, eu prefiro que este seja de múltipla escolha" (Figura 2). Esses são dados adicionais enfatizando a necessidade de Joker livrar-se dos vínculos com o seu passado e, como acontecerá ao longo da narrativa no filme, também romper com os elos no seu presente confirmando que "everything must go".
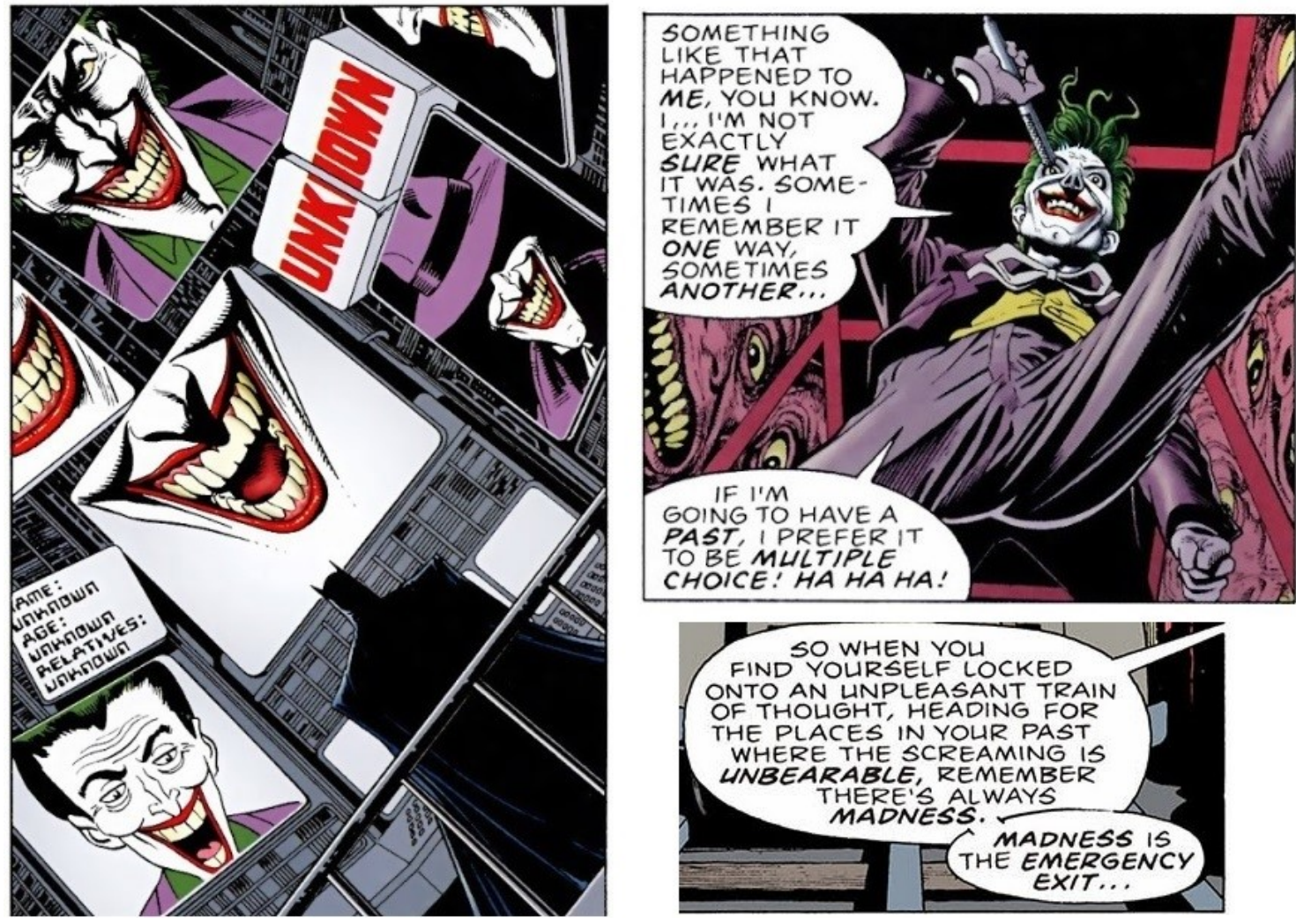

Figura 2: fragmentos da história em quadrinho The Killing Joke, 2008, atestando o desconhecimento sobre Joker e seu passado. Fonte: DC Comics.

Ainda na introdução do filme, enquanto trabalha na rua já fantasiado de palhaço, Arthur Fleck dança ao som do piano em frente a uma loja de instrumentos musicais segurando uma placa com os dizeres "everything must go". Neste momento, o expectador obviamente é levado a crer que a frase na placa faz referência à loja que irá fechar e, por conta disso, quer se livrar de todo o estoque vendendo-o a preços promocionais. Todavia, como se verá, trata-se da segunda pista do diretor Todd Phillips para a narrativa que se seguirá, mostrando que "tudo deve ir", isto é, todos os elos sociais e conexões afetivas que Arthur Fleck possui devem ser rompidos.

Enquanto Arthur Fleck dança na rua, cinco jovens roubam-lhe a placa e saem em disparada pelas ruas de Gotham City. Arthur Fleck corre atrás deles tentando recuperar a placa que lhe foi tomada. Ao adentrar em um beco perseguindo os adolescentes, um destes bate fortemente com a placa no rosto de Fleck, quebrando-a em diversos pedaços. Esse ato violento de destroçar a placa na face de Arthur Fleck reafirma o comentado sobre a primeira cena do filme, isto é, o caminho rumo à quebra dos laços sócio-afetivos será destrutivo e doloroso. Com o impacto da placa sendo quebrada em sua face, Arthur vai ao solo e é violentamente espancado pelos jovens. Um dado muito importante nesta cena é que a música começa depois do espancamento. Como será comentado, a magnífica música original, 
criada pela compositora islandesa Hildur Gudnadóttir (também ganhadora do Oscar), revelar-se-á como a outra persona no processo da transformação de Arthur Fleck em Joker.

Na cena que se segue à introdução do filme, logo após seu espancamento, Arthur Fleck está em uma sala sendo atendido por uma assistente social. Depois de um tempo de risada descontrolada, ele tem sua primeira fala: "it is just me, or is getting crazy out there?". Nesse momento somos levados a crer que ele se refere à situação da cidade, que enfrenta a crise sanitária, o lixo se acumula nas ruas e há ratos por toda parte. Todavia, é mais uma pista indicando a transformação que irá ocorrer. Ele está, na verdade, referindo-se ao seu mundo exterior que está em crise e sofrendo o processo de dissolução de uma persona. A música e seu sorriso (totalmente distinto de sua risada descontrolada) comprovam essa afirmação. A música funciona como manifestação de seu interior tentando emergir e o sorriso quase de escárnio indica que ele sabe que a atendente social não compreendeu ao que ele realmente se referia.

Além do espancamento descrito ocorrido na introdução do filme, ao longo da história, Arthur Fleck será por diversas vezes objeto de violência gratuita por parte de pessoas conhecidas e desconhecidas. Algumas dessas agressões: dentro de um ônibus, Arthur faz alguns gracejos tentando alegrar uma criança pequena que, a propósito, responde com simpatia às suas brincadeiras. A mãe da criança, sem qualquer motivo, começa a gritar e maltratá-lo, acusando-o de perturbar seu filho e pede que ele deixe a criança em paz. Em seu trabalho, seus colegas fazem piadas com ele e o consideram uma aberração. Seu chefe o trata rispidamente e não acredita quando ele diz que foi espancado e ameaça descontar de seu pagamento o valor do cartaz que lhe foi roubado. A assistente social que acompanha sua reabilitação não presta atenção ao que ele diz. O governo cancela o serviço de acompanhamento social e, consequentemente, a possibilidade de ele conseguir os medicamentos que vinha recebendo. Alfred, mordomo de Thomas Wayne, o expulsa quando ele vai à mansão Wayne tentando um encontro com o milionário. Em um banheiro de cinema, Arthur aborda Thomas Wayne, este o insulta e finaliza a conversa dando um soco em sua cara. Fleck descobre que sua mãe vinha mentindo a respeito de sua paternidade e sobre sua infância de abusos. Dentro do metrô, três corretores de ação de Wall Street o espancam. Murray Franklyn, ídolo e figura paterna de Arthur, convida-o para participar de seu talk show. Entretanto, Arthur compreende que este o convidou para o programa com intenção de zombar dele.

Todas essas agressões sofridas por Arthur Fleck ao longo do enredo vão acumulando elementos para que ele vá gradualmente desistindo de manter ou criar laços sentimentais com as pessoas e com os contextos. Ao mesmo tempo em que esses vínculos vão sendo quebrados ocorre a transformação da persona Arthur Fleck na persona Joker. Essa transformação é operada pela aceitação da persona que força sua emersão em resposta não somente às atitudes violentas dos outros, mas também pelo desapontamento e insucesso de Arthur Fleck nas várias instâncias de sua vida. Profissionalmente, ele é demitido de seu emprego como palhaço. Tenta carreira como comediante, mas é ridicularizado. Depois perde a assistência que recebida do governo. Socialmente, ele tenta alegrar uma criança, mas é reprimido, o que lhe causa frustração. Não consegue estabelecer um vínculo romântico com sua vizinha. Familiarmente, ele cuida muito bem de sua mãe, mas sente-se traído pelo fato de ela lhe haver mentido. É ridicularizado pelo apresentador de TV Murray Franklyn - seu ídolo e figura paterna. Não consegue que Thomas Wayne, seu suposto pai biológico, lhe trate com um mínimo de respeito. O insucesso nas diversas instâncias da vida, por sua vez, provoca-lhe a sensação de inadequação (unsuitability) e, por conseguinte, despertencimento.

\section{Cinematografia}

Os conflitos psicológico e identitário sofridos por Arthur Fleck, o ambiente opressivo em que vive, bem como os diversos aspectos de sua trajetória rumo à erupção da persona Joker estão espelhadas na cinematografia. Uma cena filmada em plano geral com um ângulo alto mostra a linha férrea que 
divide a cidade (Figura 3). Objetivamente, essa tomada evidencia o aglomerado de edifícios e a falta de espaço que tornam a cidade desorganizada, claustrofóbica e opressiva. Porém, simbolicamente, essa imagem faz referência à cisão identitária enfrentada por Arthur Fleck, assim dividido entre suas tentativas frustradas de agradar aos outros e a fúria interna que intenta emergir em resposta às contingências de sua vida. Note-se que há duas tomadas aéreas no filme. Além da mencionada, a outra tomada aérea ocorre depois da metade do filme e mostra um aglomerado de edifícios e o hospital Arkham. Quando comparadas, essas tomadas simbolizam a cisão de personalidades e a posterior anulação dessa duplicidade, pois a persona Joker já subjugou a persona Fleck.

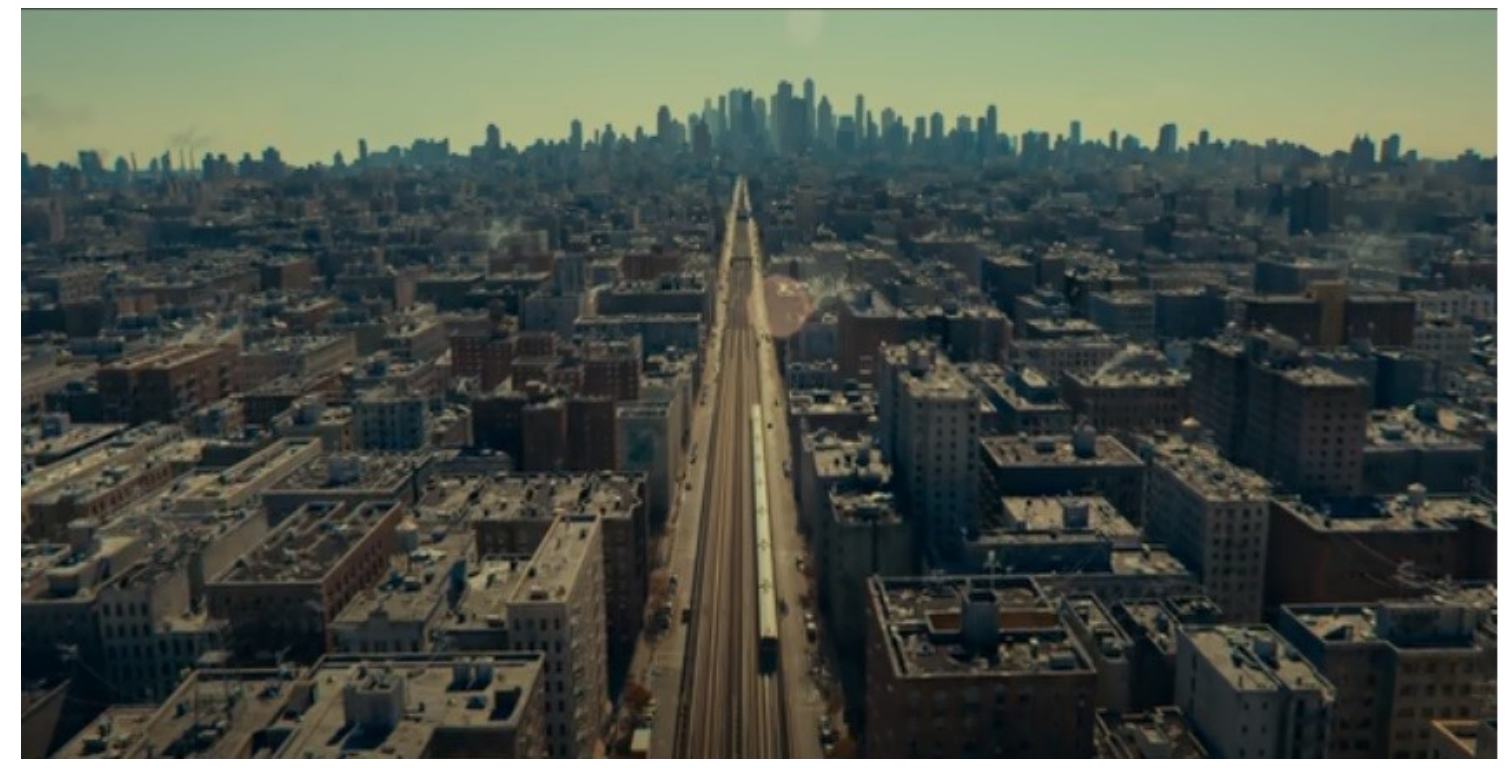

Figura 3: imagem aérea da linha férrea que divide a cidade

O mundo não é um lugar amigável para Arthur Fleck e a "saída de emergência" por ele encontrada foi abrir mão de pertencer a esse mundo e abraçar a loucura. O aspecto da hostilidade do mundo está explicitado na cinematografia, sobretudo nos enquadramentos. Quando Arthur Fleck é filmado em um plano médio, está sempre em locais pequenos, escuros, rodeado de muitos objetos de modo a produzir uma sensação claustrofóbica, de confinamento e de opressão (Figuras 4,5 e 6). Nos planos abertos ele quase desaparece no plano de fundo, criando a sensação do ser humano diminuído e invisível à sociedade (Figura 7).
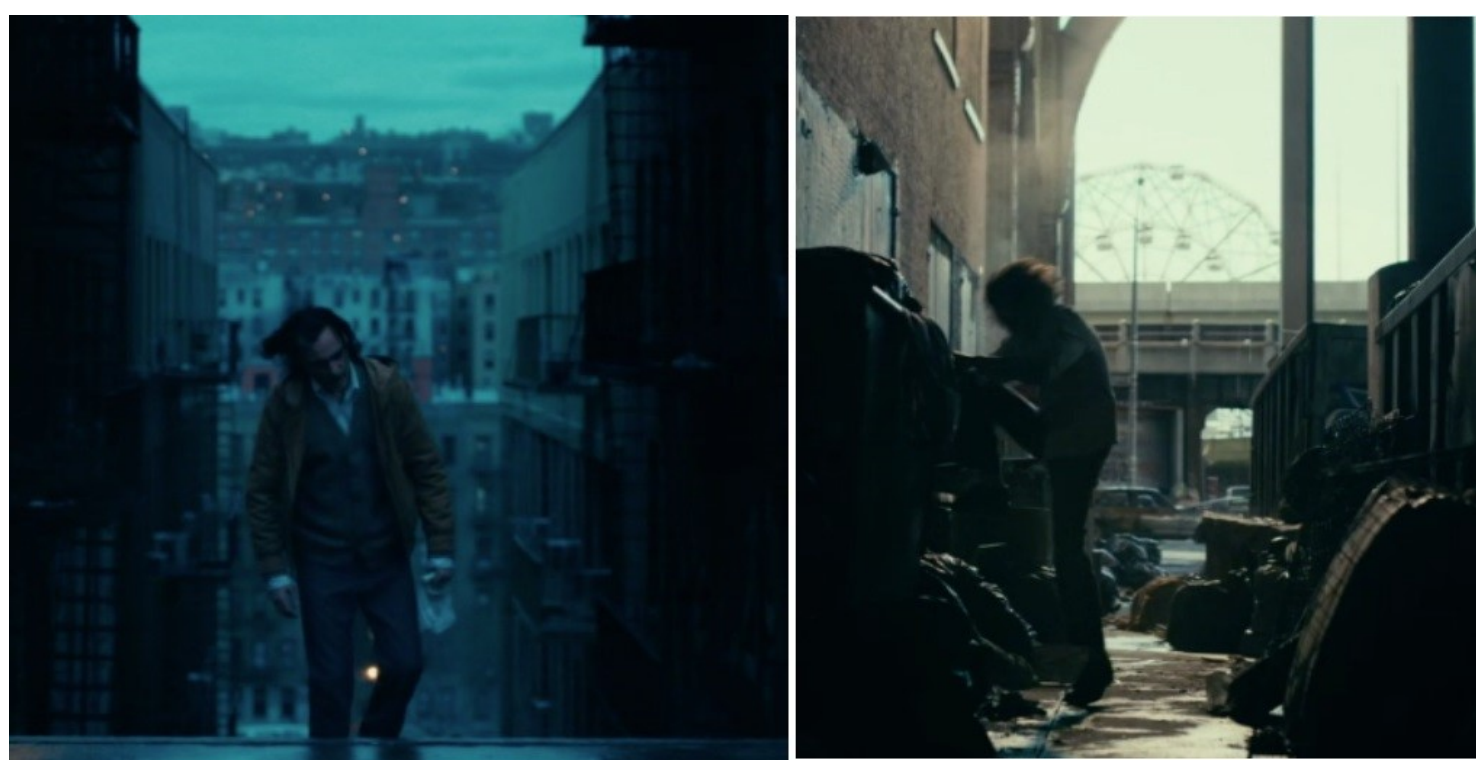

Figura 4: enquadramento em contextos confinatórios

R. Inter. Interdisc. Art\&Sensorium, Curitiba, v.7, n.2, p. 082 - 100 Jul.- Dez. 2020 

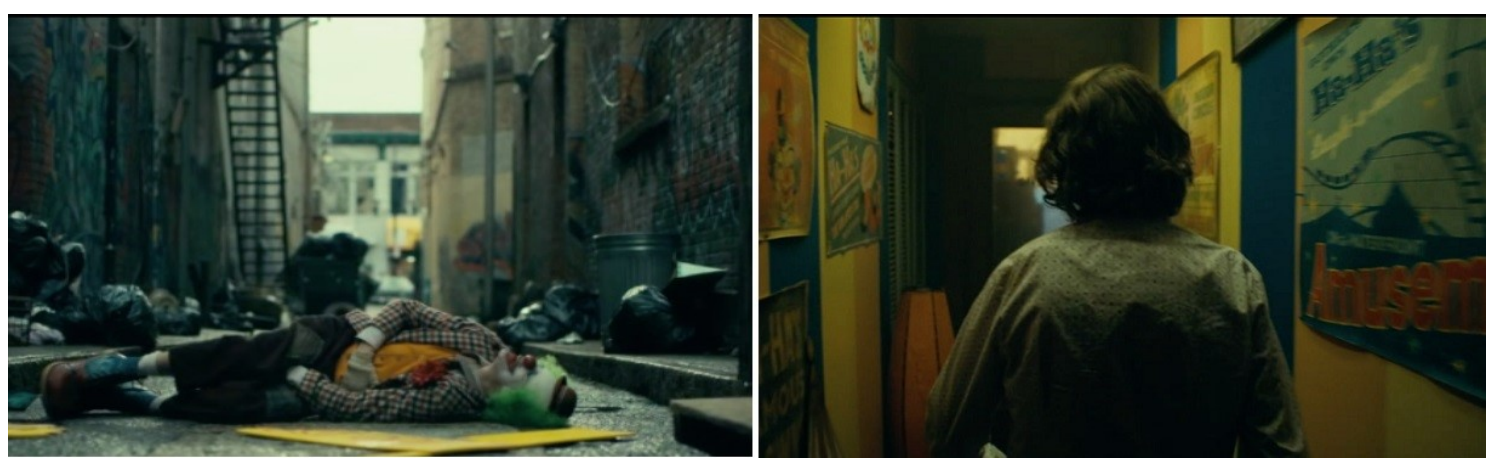

Figura 5: enquadramento em contextos confinatórios
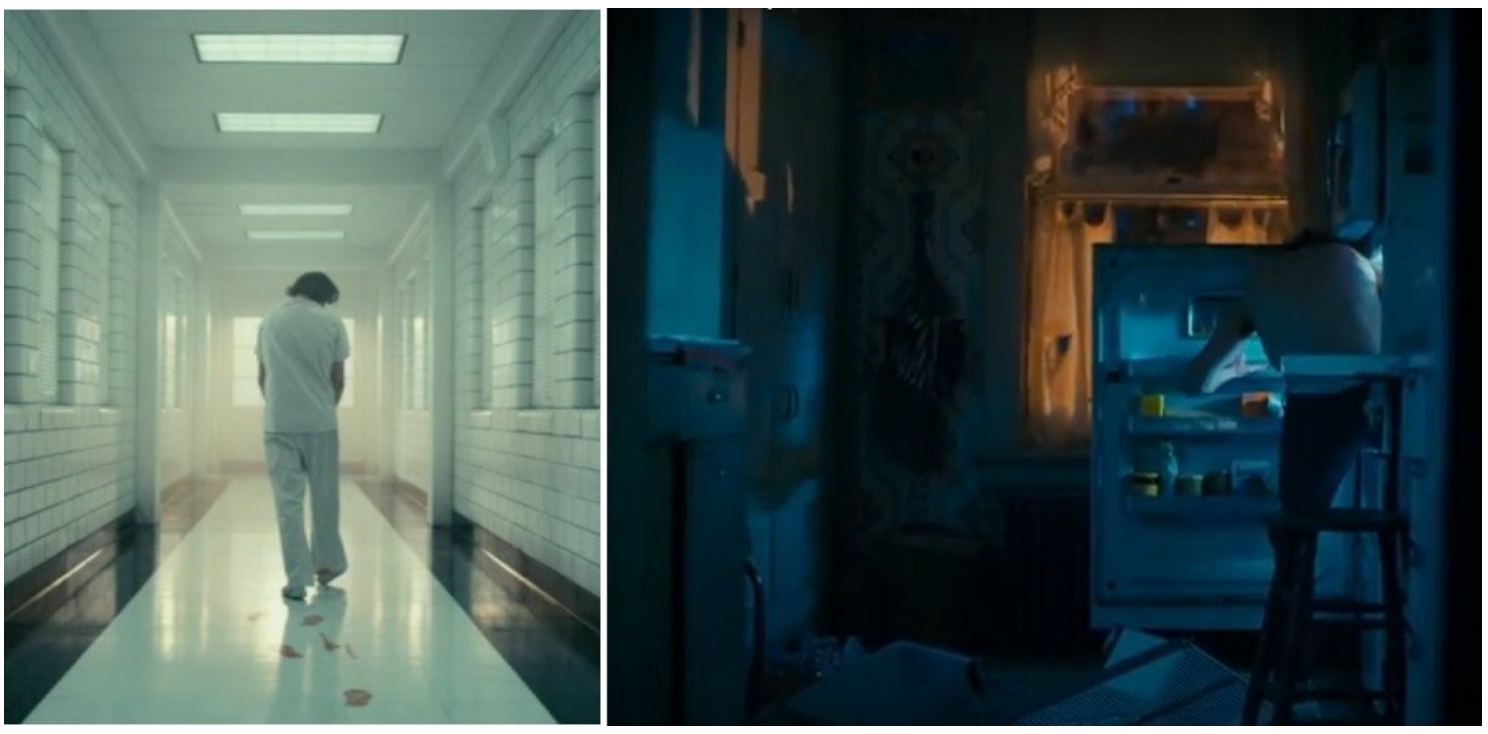

Figura 6: enquadramento em contextos confinatórios

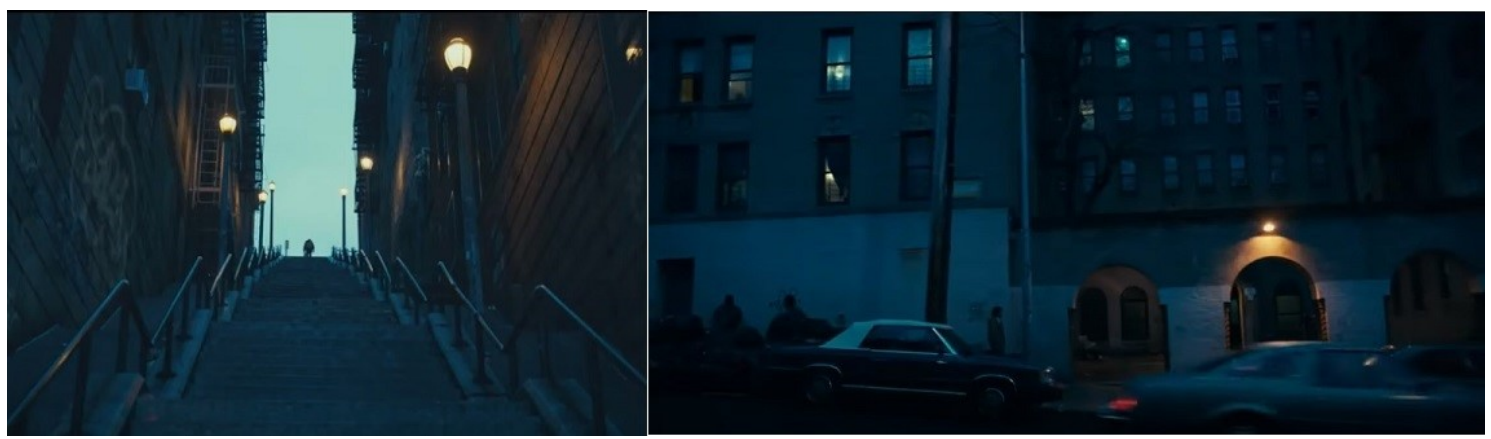

Figura 7: plano aberto, indivíduo invisibilizado

O posicionamento do personagem confinado entre duas paredes ajuda a interpretar uma das cenas mais enigmáticas do filme. Após ter confrontado Thomas Wayne, seu suposto pai biológico, o milionário lhe diz que, na verdade, sua mãe sofre de doença mental e que Arthur havia sido adotado por ela. Ele, novamente frustrado, completamente abalado e irado, volta para o seu apartamento e, outra vez, é mostrado posicionado em um ambiente confinado, como que espremido entre duas paredes. Em um estado de agitação, ele começa a tirar as coisas de dentro de sua geladeira (Figura 6) e, depois de esvaziá-la, entra nela e fecha a porta. Após uns segundos nada acontece e não se sabe se ele morreu ou não. O silêncio é quebrado pelo toque do telefone. No entanto, trata-se de uma elipse, e a próxima cena já se passa na manhã seguinte, e nos mostra ele atendendo à ligação. A estranheza e a dúvida causadas pela cena anterior persistem: por que ele entrou no refrigerador? Foi uma tentativa 
de suicídio? Penso que justamente a cinematografia oferece uma pista para uma possível resposta. As paredes simbolizam seu mundo fechado, carente de opções. Ele desde o início tenta encontrar modos para escapar desse ambiente opressivo, mas não logra sucesso. Neste último ato de desespero buscando uma "saída de emergência" ele vislumbra a única porta ao seu redor, justamente a porta do refrigerador. Todavia, essa saída não é possível e ele se dá conta que não há saída. Na verdade, a única opção é, como citado anteriormente, aceitar sua persona Joker (veja balão de diálogo na Figura 2) que neste momento já se manifestou, mas ele ainda tem outros laços a romper. E é exatamente a quebra dos últimos vínculos que se dará nas cenas seguintes: ele mata sua mãe, seu colega de trabalho que lhe havia dado uma arma, o apresentador Murray Franklyn (figura paterna) e, na última cena do filme, matará também a psicóloga do hospício Arkham. Há, ainda, a "necessária" morte de Thomas Wayne, porém, esta irá ocorrer pelas mãos de outra pessoa fantasiada de palhaço. É importante notar que todo o filme se passa a partir das descrições de Arthur Fleck, ou seja, ele é o narrador da história e, por conta disso, está sempre presente nas cenas. $\mathrm{O}$ único momento do filme em que Joker, já não mais Arthur Fleck, não participa (e, portanto, paradoxalmente, não o poderia ter contado) é o assassinato de Thomas e Martha Wayne em um beco na saída do cinema. A morte de Wayne é necessária justamente porque ainda há a remota possibilidade de ele ser realmente o pai biológico de Arthur Fleck; todavia, como este passado deve ser desconhecido ou ficar em suspenso (vide Figura 2) e pelo fato, estabelecido desde o início da história, de todos os vínculos terem que ser rompidos, então Thomas Wayne deve ser eliminado. Um ponto interessante e bem sutil (e que passou despercebido em muitas análises do filme) é o fato de o palhaço que atira em Thomas Wayne repetir a mesma frase dita por Joker no programa de TV antes de atirar em Murray Franklyn: "you get what you fucking deserve!"'. Desse modo, o diretor não se afasta totalmente do universo DC Comics e estabelece um motivo para a rivalidade futura entre Batman e Joker, pois Bruce Wayne, ainda criança, presencia o assassinato de seus pais por uma pessoa que, mesmo não sendo o próprio Joker, agiu motivada por ele.

Cinematograficamente, a mencionada ruptura de vínculos é também suportada por uma contagem regressiva discretamente inserida nas imagens en passant que conduzem ao momento final de aceitação de sua outra persona, ou seja, o momento em que ele deixa de ser Arthur Fleck e se assume definitivamente como Joker. A contagem regressiva tem início justamente no momento divisor de águas do filme, isto é, quando ele mata os três corretores de ações que o espancavam dentro de um vagão do metrô. A plataforma onde Arthur Fleck atira nos yuppies de wall-street mostra o número 9. Depois Arthur entra no apartamento de número 8B de sua vizinha Sophia. Quando vai a Arkham o número mostrado na parede é 7 . Fugindo de dois detetives, ele entra no metrô cheio de pessoas fantasiadas de palhaços e aparece o número $6 \mathrm{em}$ um dos pilares da plataforma. Ao escapar dos detetives, Arthur faz gesto com as mãos mostrando os 5 dedos. Ao conversar com o apresentador de TV Murray Franklyn, o número 4 é visto na parede dos fundos do corredor dos camarins. Ao entrar no palco, Joker é filmado pela câmera de número 3. Após assassinar ao vivo Murray Franklyn, várias emissoras de canais divulgam a notícia e uma dessas emissoras destacada é o canal de número 2. Por fim, o carro de polícia que o leva preso passa em frente a um letreiro luminoso mostrando o nome do teatro "ACE In The Hole" (ou seja, a carta ás que equivale a 1 no baralho) ${ }^{10}$.

A contagem regressiva bem como a preparação de Joker para participar do programa de TV levam o expectador a esperar pelo seu suicídio, pois várias vezes ele coloca a arma em sua boca insinuando que irá terminar a entrevista se matando. Porém, essa expectativa é novamente quebrada quando, ao invés de cometer suicídio, ele elimina o último vínculo sentimental que ainda possuía matando Murray Franklyn, sua figura paterna.

10 Há diversos sites na Internet mostrando em imagens essa contagem regressiva, por exemplo: https://www.youtube.com/watch?v=V21sJj4x2s\&t=1s ou https://www.youtube.com/watch?v=r0k5n2EUnNU

R. Inter. Interdisc. Art\&Sensorium, Curitiba, v.7, n.2, p. 082 - 100 Jul.- Dez. 2020 


\section{Música e corpo como expressões do inefável}

É realmente impressionante a transformação corporal do ator Joaquin Phoenix, não somente por ter emagrecido 23 quilos, mas principalmente pela forma como expressou no corpo a dissolução da persona Arthur Fleck e a emersão de Joker. Trata-se de um discurso corporal que extravasa seus sentimentos profundos e seu corpo é o veículo para essa eclosão. Sem poder expressar-se como palhaço ou comediante, tendo sua voz reprimida por muitos, sendo portador de uma condição psíquica que lhe causa descontrole nervoso e o impede de se manifestar propriamente, a opção que lhe resta para lidar com a hostilidade do mundo e externar seus sentimentos é o seu corpo. Por essa razão, em diversas cenas Arthur Fleck dança. Sua dança é sempre expressão de segurança, controle e realização, oposto ao riso que indica insegurança, descontrole e nervosismo. Um dos momentos mais evidentes desse discurso corporal ocorre após ele matar os três corretores que o agrediam em um vagão do metrô. Fugindo desesperadamente da cena do crime, ele entra em um banheiro. Completamente abalado com o ocorrido ele olha no espelho como que buscando uma resposta para o que deveria fazer e essa resposta vem pelo extravasamento da emoção por meio de uma performance corporal que não é dança nem ginástica, mas uma mistura de ações corporais que não somente o acalmam, mas o fazem perceber que ele tem uma forma de lidar com o mundo, e essa forma é deixar Joker aflorar. Nos outros episódios com dança, ocorridos no filme até esse ponto, sempre havia uma música diegética. Entretanto, na cena que ocorre no banheiro a música vem de dentro dele e representa justamente a persona Joker emergindo. Nesse momento, Arthur Fleck aceita sua transformação e esta é explicitada em toda sua postura corporal que muda de apático para altiva, de tímida para confiante e de abatido para empoderado. Nas cenas posteriores, essa metamorfose será corroborada no figurino, pois ele deixará de vestir roupas com tons apagados e passará a usar cores vibrantes.

A música original composta para Joker está absolutamente integrada à narrativa do filme e pode ser considerada como uma personagem da história (justamente, o Joker). O tema é baseado no intervalo de terça menor tocado na região grave no violoncelo solista sobre uma massa sonora de cordas tocando muito suavemente sul ponticello - o que atribui uma sonoridade mais metálica e estridente criando o contraste com o som grave do tema. Junto com o cello ouve-se um ritmo constante marcado ora pelo tímpano ora por um som de percussão eletrônica como se fosse um cronômetro prenunciando uma explosão. Nas faixas Call me Joker e Hiding in the Fridge, por exemplo, o violoncelo executa vários efeitos timbrísticos não convencionais, rompendo como manifestações excruciantes dos desejos da personagem. A vontade reprimida manifesta-se, assim, por meio da música e funciona como evidência da transformação da personagem. Por exemplo, na primeira cena de espancamento ocorrida no beco, a música começa alguns segundos após a agressão terminar. Ao ser repreendido pelo seu chefe por conta do cartaz sumido, Arthur Fleck sente-se injustiçado e a fúria interior é manifestada pela música, intensificada gradualmente, mas durante a fala do chefe culpando-o pelo sumiço da placa. Esse sentimento de injustiça é "aliviado" chutando sacos de lixo acumulados em um beco. Quando Arthur Fleck é espancado no metrô pelos yuppies de wall street a música já soa com um intervalo de tempo menor após o início da agressão. Quando ele se refugia no banheiro após matar os corretores a música vem de dentro dele e não é manifestação de fúria, mas da erupção da nova persona. Após a metamorfose em Joker, a música antecede suas ações violentas, antecipando o ataque, como quando ele mata seu colega de trabalho que lhe deu a arma, indicando assim que a persona Joker já está no controle.

As outras músicas não originais inseridas no filme representam a condição de injustiça em que a personagem se encontra, bem como a sua vontade de reverter essa situação. A canção That's Life (Dean Kay \& Kelly Gordon, gravada por Frank Sinatra) descreve os altos e baixos da vida e a vontade da pessoa em tomar o controle desta, como, por exemplo, nas duas estrofes no quadro abaixo: 


\begin{tabular}{|l|l|}
$\begin{array}{l}\text { That's life (that's life), that's what all the } \\
\text { people say }\end{array}$ & $\begin{array}{l}\text { a vida é assim (assim é a vida), é o que todas } \\
\text { as pessoas dizem }\end{array}$ \\
\hline You're ridin' high in April, shot down in May & $\begin{array}{l}\text { Você está voando alto em abril, abatido em } \\
\text { maio }\end{array}$ \\
\hline But I know I'm gonna change that tune & Mas eu sei que vou mudar esse bordão \\
\hline When I'm back on top, back on top in June & Quando estiver de volta ao topo, em junho \\
\hline That's life (that's life), I tell you I can't deny it & $\begin{array}{l}\text { a vida é assim (assim é a vida), eu te digo, eu } \\
\text { não posso negar }\end{array}$ \\
\hline $\begin{array}{l}\text { I thought of quitting, baby, but my heart just } \\
\text { ain't gonna buy it }\end{array}$ & $\begin{array}{l}\text { Eu pensei em desistir, baby, mas meu coração } \\
\text { simplesmente não vai aceitar }\end{array}$ \\
\hline And if I did think it was worth one single try & $\begin{array}{l}\text { E se eu pensasse que valeria uma única } \\
\text { tentativa }\end{array}$ \\
\hline I'd jump right on a big bird and then I'd fly & $\begin{array}{l}\text { Eu pularia direto em um pássaro grande e } \\
\text { depois voaria }\end{array}$
\end{tabular}

Essa música é usada no talk show de Murray Franklyn, mas é também a música dançada por Joker quando ele se prepara para a participar desse programa de TV, indicando, justamente, seu desejo em tomar o controle.

Assim como os pobres e doentes mentais, outras minorias alvo de preconceito são apresentadas de modo sutil ou explícito. A comunidade judaica, por exemplo, é insinuada discretamente por um comediante de stand up que ironiza que trabalha como professor usando um nome falso, "pois eles não contratam judeus". A comunidade afro-americana é apresentada de modo mais categórico. Arthur Fleck assiste TV em seu apartamento e dança com a arma na mão ao som da canção Slap that Bass (George Gershwin) - música essa que faz parte do filme musical "Shall we Dance" (1937) estreado por Fred Astaire. A cena na TV apresenta trabalhadores negros que cantam enquanto limpam a casa de máquinas de um navio (Figura 8). Essa versão é cantada pelo famoso ator Dudley Dickerson e Astaire, que também improvisa o sapateado. A letra obviamente tem cunho político ideológico, mas em Joker, além disso, reitera a condição de conformismo e de exploração em que se encontram as minorias desassistidas da sociedade, minorias estas em que Arthur Fleck se inclui.

\begin{tabular}{|l|l|} 
Zoom zoom, zoom zoom & Zoom zoom, zoom zoom \\
\hline The World is in a mess & O mundo está uma bagunça \\
\hline With politics and taxes & Com política e impostos \\
\hline And people grinding axes & E as pessoas afiando seus machados \\
\hline There's no happiness & Não há felicidade \\
\hline Zoom zoom, zoom zoom & Zoom zoom, zoom zoom \\
\hline Rhythm lead your ace & Ritmo conduz seu ás \\
\hline The future doesn't fret me & O futuro não me preocupa \\
\hline If I can only get me & Se eu apenas conseguir \\
\hline Someone to slap that bass ${ }^{11}$ & Alguém para tocar esse baixo
\end{tabular}

\footnotetext{
${ }^{11}$ Slap é o nome de um golpe típico na técnica usada em alguns instrumentos musicais (como congas e guitarra elétrica) e, neste caso, no contrabaixo. O slap produz um som percussivo nos instrumentos de corda. Para a realização do slap, no
} 


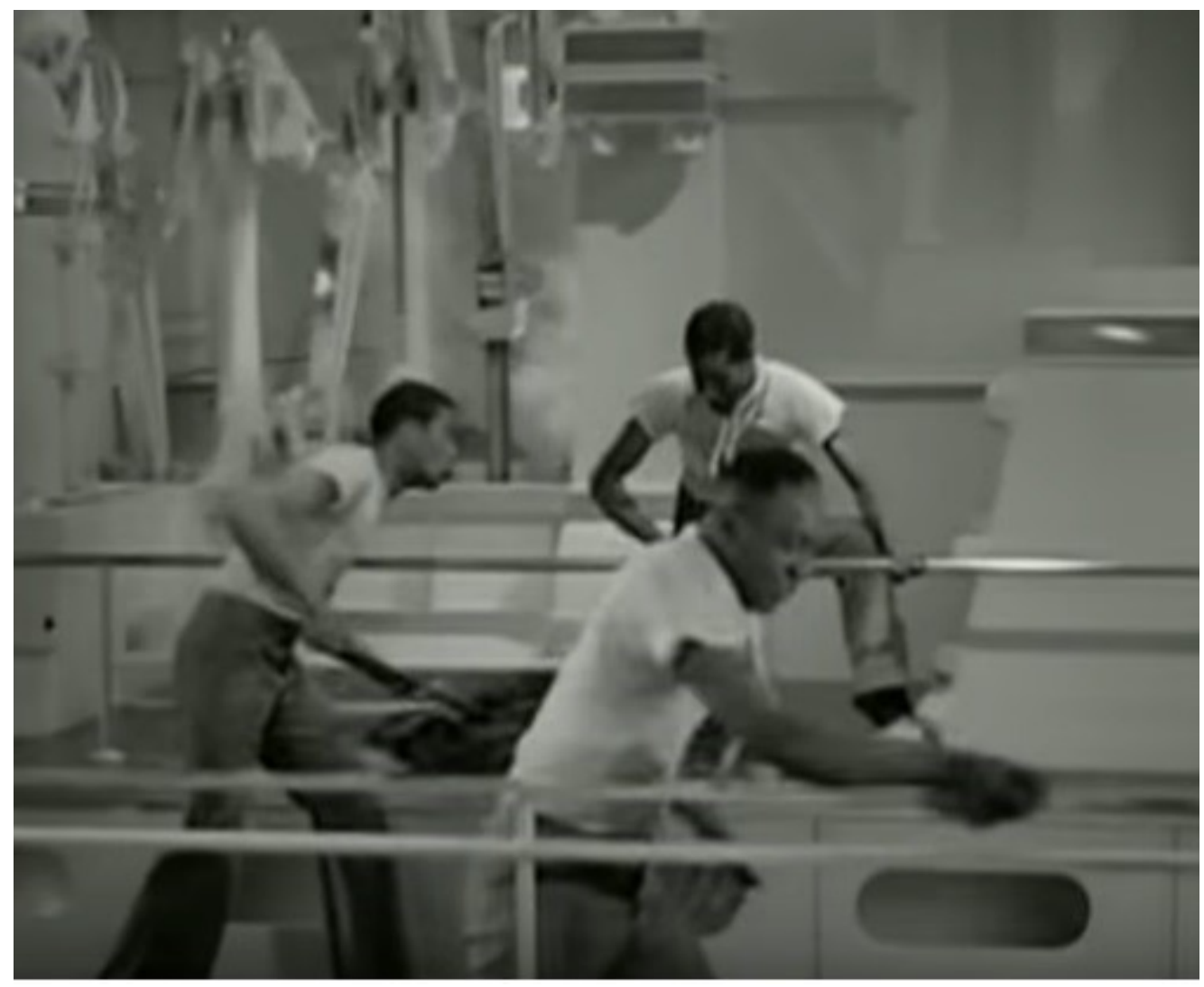

Figura 8: trabalhadores afro-americanos cantam Slap that bass

Joker considera a si mesmo como parte de uma minoria desfavorecida. Frases no seu diário e sua fala no programa de TV confirmam esse sentimento. Ele também é simpático a essas minorias, como atestado pelo fato de ele não matar o anão, seu colega de trabalho, quando este e o palhaço que lhe deu a arma vão ao seu apartamento. Ele mata o bully, mas trata com carinho o anão.

O teor político é reforçado em outra citação inserida no filme. Quando Fleck consegue entrar clandestinamente em um cinema à busca de Thomas Wayne, a elite da sociedade de Gotham que lá se encontra assiste a Tempos Modernos (1936) com Charles Chaplin, filme que também mostra um indivíduo diminuído e invisibilizado na sociedade industrial que transforma seres humanos em meros autômatos. Esse aspecto espelha justamente o sentimento de Arthur Fleck que não entende por que o mundo o trata com indiferença. Esse sentimento de ser invisível é também mostrado quando ele tenta entrar no hospital em que sua mãe está internada. Como a porta não abre, ele, com raiva, pula e faz gestos buscando se fazer notar e assim chamar a atenção de alguém, entretanto, sem perceber que tenta entrar por uma porta automática de saída e, portanto, esta não abre.

$\mathrm{O}$ aspecto da invisibilização e equalização dos indivíduos na sociedade pós-industrial é também discutido no filme na rebelião que se instaurou em Gotham após "um palhaço" ter assassinado os jovens corretores de ação. Thomas Wayne, candidato a prefeito, lamenta a morte dos jovens dizendo que "não os conhecia, mas sabia que eram pessoas boas e decentes". Sua opinião é tendenciosa e é claro o favoritismo em prol dos jovens, classificados como "boas pessoas" simplesmente pela proveniência sócio-financeira. A seguir, Wayne chama todos os cidadãos pobres de palhaços, o que funciona como estopim para a rebelião sob o mote "kill the rich". Os participantes da rebelião adotam e usam uma máscara de palhaço. $\mathrm{O}$ uso da máscara não pode ser interpretado como a simples vontade

contrabaixo, o músico pode percutir a corda com o seu polegar ou estica-la e soltá-la rapidamente contra o braço do instrumento.

R. Inter. Interdisc. Art\&Sensorium, Curitiba, v.7, n.2, p. 082 - 100 Jul.- Dez. 2020 
de não serem identificados pela polícia, pois o que intentam é exatamente a afirmação de pertencimento ao movimento. Porém, o uso da máscara é também metáfora da não individualidade com que os cidadãos são tratados pelos políticos, ou seja, são, falaciosamente, considerados como uma turba equalizada, alienada e ansiosa em promover o caos. Todavia, não há qualquer discussão por parte do candidato sobre se aquilo que reivindicam é justo ou não. Note-se que Joker não quer se envolver com a rebelião ou com a política. Um indicativo do desinteresse pelo movimento é a cena em que Joker coloca a máscara de palhaço para escapar dos policiais que o perseguem. Porém, assim que consegue livrar-se deles, tira a máscara e a joga em uma lixeira. Ainda, no programa de TV ele atesta que "não é político, apenas quer fazer as pessoas rirem". Essa afirmação também explica seu gesto, na casa de Thomas Wayne, ao colocar forçadamente um sorriso na cara de Bruce Wayne que, por sua vez, não achava graça e respondia com indiferença às suas brincadeiras.

Há outros momentos em que a estratificação social é enfatizada na narrativa com imagens. Entre outros, é óbvio o contraste entre os ônibus e trens que levam aos bairros pobres, mostrados totalmente sujos, pichados e violentos, e o trem que leva ao bairro rico, com trens impecavelmente limpos e pessoas engravatadas lendo jornais. Justamente, esse contexto social funciona como um disparador da rebelião instaurada na cidade e, também, atua pressionando Arthur Fleck na sua transformação.

\section{$O$ contexto social como personagem de impacto}

O estudo de personagem realizado pelo diretor Todd Phillips também permite a reflexão a respeito da ação do contexto social como propulsor da mudança ocorrida com a personagem principal. Neste sentido, o contexto permite ser considerado como mais um personagem do enredo, justamente, o personagem de impacto. Adotando a definição usual de personagem de impacto como aquele que atiça os conflitos internos do personagem principal objetivando conduzi-lo a uma mudança pelo enfrentamento de certos desafios, percebe-se que essa condição é operacionalizada pelo mundo habitado por Artur Fleck.

A personagem principal (enquanto Arthur Fleck) tenta, sem sucesso, encontrar algum pertencimento, seja criando vínculos no trabalho, na família ou no plano sentimental. As circunstâncias por ele enfrentadas, entretanto, e a reação do meio em resposta ao seu modo de agir forçam a eclosão da persona Joker. Ao assumir essa persona, ele já não quer mais pertencer a nada, daí o significado da mencionada cena da máscara sendo jogada na lixeira e das mortes que acontecem posteriormente.

A falta de pertencimento, como verificado em muitas pesquisas acadêmicas, pode levar ao suicídio ou à loucura - ambas possibilidades aventadas em Joker. Sebastian Junger (2014) e Jake Wood (2011), por exemplo, em suas respectivas palestras no Ted Talks, ao considerarem os efeitos do stress pós-traumáticos em veteranos de guerra, observaram que aqueles que cometeram suicídio o fizeram justamente por não terem conseguido encontrar, no retorno aos Estados Unidos, o sentimento de pertencimento a uma causa assim como possuíam na guerra. Wood, em uma passagem, explica que um veterano de guerra "suicidou-se não por conta do que aconteceu no Iraque ou no Afeganistão, mas em razão daquilo que ele perdeu quando retornou à sua casa. Ele perdeu propósito. Ele perdeu sua comunidade e talvez, mais tragicamente, sua autoestima" (Wood, 2011). Similarmente, o filme Taxi Driver (1976), dirigido por Martin Scorsese (uma das referências do diretor Todd Phillips para seu estudo de personagem realizado em Joker), explora essa temática do retorno de um militar de um contexto de guerra e a busca de um novo propósito para dar sentido à sua vida.

Pesquisando em outro contexto completamente distinto, a antropóloga Chelsea Strayer apresenta dentre os resultados de seu convívio de mais de dois anos com tribos de Gana (África ocidental) um estudo aprofundado sobre como, ao longo da história, a espécie humana se tornou tão sensível às situações vividas no ambiente social, e conclui que "pertencimento e ostracismo literalmente fazem a diferença entre vida e morte" (2013). 
Ao lado disso, o contexto atua fortemente nos mecanismos cognitivos, nos modos e formas como conhecemos e criamos sentido acerca dos estímulos percebidos. Kiss comenta que "não é que as características externas têm uma influência causal na cognição, mas o elo interativo entre organismo e meio ambiente torna-se parte do processamento cognitivo ${ }^{12 "}$ (Kiss, 2015, p.46). A afirmação de Kiss, fundamentada sobretudo na cognição incorporada, compreende que o meio circundante desempenha uma função primordial na consciência proprioceptiva, pois "o cérebro está incorporado e o corpo está situado em seu ambiente físico circundante ${ }^{13 "}$ (Kiss, 2015, p.45).

No caso de Joker, o descobrimento da sua própria história de vida é operacionalizado por meio da integração cognitiva com o seu meio que, como comentado, é confinado, claustrofóbico, inseguro, cruel e construído sobre mentiras. A decisiva percepção de Arthur Fleck a respeito de si mesmo ocorre em um dos momentos mais chocantes do filme, quando ele mata a pessoa para quem havia dedicado toda a vida: sua mãe. $\mathrm{O}$ alto grau de significado dessa cena para a narrativa não se dá somente porque ele rompe com um vínculo existencial e afetivo importante, mas porque nesse momento ele descobre a farsa de sua própria vida e a falsidade do doutrinamento que lhe havia sido imposto por sua mãe. Antes de matá-la ele diz: "Eu pensava que minha vida era uma tragédia, mas agora eu percebi que é uma comédia de merda!" "14. Essa espécie de epifania é um divisor de águas, pois é exatamente nesse momento que ocorre a mudança definitiva na personagem. Durante a vida, sua mãe sempre lhe dizia "ponha um sorriso em sua cara" 15 . Cinematograficamente, o rompimento com esse condicionamento é mostrado quando Joker rabisca as palavras "forget to" de um cartaz afixado em seu local de trabalho com os dizeres "Do not forget to smile" e modifica-o para "Do not smile".

Como pode ser percebido, o sorriso, a risada, o humor e a comédia são características importantes da narrativa do filme. Se compreendermos narrativa como "a interpretação global da mudança de dados" (Branigan, apud Kiss, 2015, p.48), observaremos que a narrativa acontece nos níveis do conteúdo textual, da expressão corporal e, inclusive, no discurso da própria personagem. Esta é evidenciada na passagem dos diálogos inseguros, tímidos e claudicantes (como mostrado nas seções que teve com a assistente social no início do filme) para a argumentação segura e incisiva de Joker - como se dá durante sua entrevista com Murray Franklyn no programa de TV. Quando Joker confessa a Murray ter matado os corretores de wall street, o apresentador o confronta: "você acha que matar aqueles caras é engraçado?". A resposta de Joker é surpreendentemente racional: "Eu acho. E estou cansado de fingir que não é. Comédia é subjetiva, Murray. Não é o que dizem? Todos vocês, o sistema que sabe tanto, vocês decidem o que é certo ou errado ... da mesma forma que decidem o que é ou não engraçado!"16. Joker não está tentando justificar a violência, porque ele acha mesmo que agiu corretamente ao matar os corretores que o agrediam, mas argumenta sobre seu direito de poder satirizar e achar engraçado atos que poderiam ser considerados não éticos, pois afinal, quem decide o que é ou não ético?

Coëgnarts e Kravanja (2015), em seu estudo sobre a percepção da ética nas personagens de filmes, lembram que o neurocientista Antonio Damásio já havia chamado à atenção para o fato de que ações morais não dependerem somente das faculdades cognitivas superiores. Ele demonstrou que "pacientes com danos no córtex pré-frontal, um centro responsável pelo processamento de emoções no cérebro, porém, cujas capacidades lógicas permaneceram intactas [...] não eram mais capazes de

\footnotetext{
${ }^{12}$ It is not simply that external features have a causal influence on cognition, but that the interactive link between organism and environment becomes part of the cognitive processing.

${ }^{13}$ The brain is embodied, and the body is situated in its surrounding physical environment.

${ }^{14}$ No original: "I used to think my life was a tragedy, but now I realized it's a fucking comedy!"

${ }^{15}$ No original: "Always put a smile on your face".

${ }^{16}$ No original: Murray: Do you think that killing those guys is funny? Joker: I do. And I'm tired of pretending it is not. Comedy is subjective, Murray. Is it not what they say? All of you, the system that know so much, you decide what is right or wrong ... the same way that you decide what is funny or not!
} 
agir moralmente. Isso sugere fortemente que há algo no raciocínio moral que vai além do objetivismo $^{17}$ (Damásio, apud Coëgnarts e Kravanja, 2015, p.273).

Interessante pensar que, historicamente, o humor é uma forma validada para se lidar com situações complexas. Os sátiros, o bobo da corte e os palhaços, entre outros, tinham a prerrogativa de poder satirizar situações sérias. Joker, entretanto, acha graça naquilo que faz porque somente ele entende. Os outros não riem de suas piadas, justamente porque ele satirizou fatos tidos como antiéticos desde a perspectiva alheia. Na TV, por exemplo, ele vai contar uma piada e olha para seu diário e vê a anotação do que havia chamado, na conversa com a assistente social no início do filme, de coleção de comentários e pensamentos engraçados. É possível ler o trocadilho: "I hope my death makes more cents than my life". Mas, como a assistente já o havia reprimido inquirindo se ele achava aquilo engraçado, ele desiste e conta uma piada sobre um policial que vai dar a notícia a uma mãe que seu filho havia morrido. Murray e a outra entrevistada o repreendem imediatamente e ela diz com repúdio: "você não pode fazer piada sobre isso!". No entanto, a argumentação de Joker interroga, justamente, por que a violência contra a pessoa caída na rua (e, igualmente, contra ele mesmo ou contra a cidade) não é relevante, ao passo que à morte dos três yuppies é dada grande importância. Com isso, ele interroga a falta de equilíbrio, ou seja, o relativismo entre as situações consideradas trágicas e cômicas, pois afinal, a condição social está também servindo como critério para decidir aquilo que deve ou não ser relevado. Pessoas são seres que fazem parte de nossa comunidade moral, consequentemente, todas merecem consideração moral. Todavia, uma pessoa é "admitida" como pessoa quando a sociedade a reconhece como tal ou quando alguém se importa com ela. Como analisado, Arthur Fleck, na prática, não preenche essas condições.

${ }^{17}[\ldots]$ patients suffering from damage to the prefrontal cortex, a centre responsible for emotion processing in the brain, although most of the 'high-reason' cognitive capacities of these patients were intact, they were no longer capable of acting morally. This strongly hints that there is something to moral reasoning that goes beyond objectivism. 


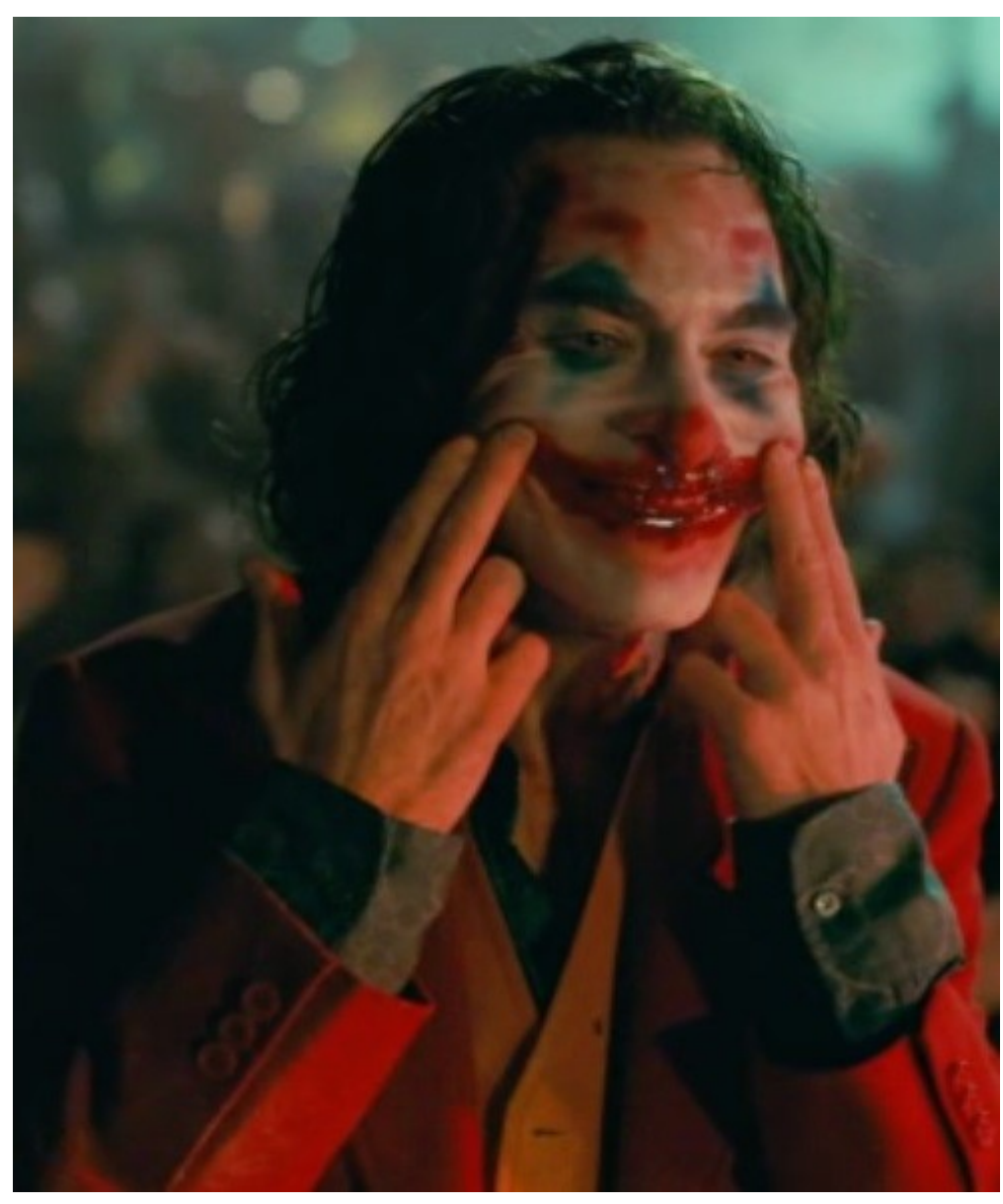

Figura 9: sorriso no rosto colocado com sangue

A narrativa sob o mote "everything must go" pode, então, ser descrita como a transformação da personagem principal de Arthur Fleck em Joker operacionalizada pelo impacto causado pelo contexto social. Assim, o sorriso inicial (Figura 1) artificial e doutrinado (put a smile on your face) torna-se um sorriso real, mas literalmente feito com sangue (Figura 9). As máscaras já não são mais disfarces, mas a própria identidade da personagem.

\section{Comentários finais}

Não se pode perder a perspectiva de que o cinema é um discurso essencialmente de imagens, e a maneira como a história é contada está estruturada na edição e disposição das sequências de cenas. Neste sentido, as várias situações ilustradas nas figuras apresentadas ao longo desse texto estão longe de constituir ao menos um resumo do filme; porém, têm o mérito de oferecer um dos estratos que compõem a rede de significações de Joker.

A sequência das cenas componentes da narrativa pode também ser formalmente analisada como uma projeção ao longo de um plano temporal (tendo como eixo divisor o momento da emersão da persona Joker) na qual as ações e condutas de Arthur Fleck são invertidos nas ações e comportamentos de Joker. O quadro a seguir mostra algumas dessas situações contrárias quando Arthur Fleck ou Joker estão no controle. 


\begin{tabular}{|c|c|}
\hline Fleck & Joker \\
\hline Pinta o sorriso com tinta em seu rosto & pinta o sorriso em seu rosto com sangue \\
\hline $\begin{array}{l}\text { Persegue os jovens que the roubaram o } \\
\text { cartaz }\end{array}$ & $\begin{array}{l}\text { É perseguido pelos detetives. Ele se safa } \\
\text { e joga fora a máscara de palhaço. }\end{array}$ \\
\hline É espancado por jovens & Mata os jovens corretores de ações \\
\hline É atendido pela assistente social & Mata a psicóloga de Arkham \\
\hline $\begin{array}{l}\text { Através da janela do ônibus é filmado } \\
\text { totalmente abatido e derrotado }\end{array}$ & $\begin{array}{l}\text { Através da janela do carro da polícia, ri } \\
\text { confiante do caos instaurado na cidade }\end{array}$ \\
\hline $\begin{array}{l}\text { Sobe a escadaria mostrando cansaço e } \\
\text { abatimento }\end{array}$ & cadaria dançando \\
\hline $\begin{array}{l}\text { Imagina estar no programa de TV de Murray } \\
\text { Franklyn }\end{array}$ & $\begin{array}{l}\text { Mata Murray Franklyn (sua figura } \\
\text { paterna) }\end{array}$ \\
\hline Cuida de sua mãe (alimenta, dá banho) & Mata sua mãe \\
\hline Recebe a arma do colega de trabalho & $\begin{array}{l}\text { Mata o colega de trabalho que havia lhe } \\
\text { dado a arma }\end{array}$ \\
\hline Segue, secretamente, sua vizinha pelas ruas & $\begin{array}{l}\text { Invade, confiante, o apartamento da } \\
\text { vizinha }\end{array}$ \\
\hline $\begin{array}{l}\text { No trabalho, é repreendido verbal e } \\
\text { injustamente pelo chefe, mas mantem-se } \\
\text { passivo }\end{array}$ & $\begin{array}{l}\text { Vai ao local de trabalho retirar suas } \\
\text { coisas (soca o relógio de ponto e rabisca } \\
\text { o cartaz) }\end{array}$ \\
\hline Leva um soco de Thomas Wayne & Thomas Wayne é assassinado no beco \\
\hline
\end{tabular}

Joker foi um filme que causou grande expectativa e diferença de posicionamentos à época de seu lançamento. Os fãs da franquia Batman, que esperavam por um filme de ação de entretenimento fácil, ficaram decepcionados, justamente, pelo conteúdo sério e artístico de Joker. Alguns chegaram a considerar o filme perigoso e manifestaram preocupação sobre possíveis tiroteios em massa motivados pelo teor político do filme (o que, obviamente, não aconteceu). Alguns comentaristas dispararam críticas contundentes sobre o conteúdo do filme. Richard Brody (2019), crítico do jornal The New Yorker, além das duras ressalvas apresentadas à interpretação de Joachim Phoenix, manifestou-se sobre Joker dessa maneira: "O resultado é um filme de um cinismo tão vasto e difundido que torna a experiência de visualização ainda mais vazia do que sua estética estúpida. [...] A incoerência temática de Joker é inseparável de seu vazio estético ${ }^{18}$ ". Do lado dos comentários menos emocionais e mais contextualizados, David Rooney (Hollywood Reporter, 2019), logo após a exibição de Joker no festival de cinema de Veneza, afirmou:

'Joker', construído em torno de uma espiral verossímil de solitário a assassino enlouquecido, é tanto um estudo de caráter psicológico neo-noir, baseado na alienação urbana e estilizado como Taxi Driver, quanto um retrato de ascensão do

\footnotetext{
${ }^{18}$ The result is a movie of a cynicism so vast and pervasive as to render the viewing experience even emptier than its slapdash aesthetic does. [...] The thematic incoherence of "Joker" is inseparable from its aesthetic emptiness.
} 
super vilão. É, sem dúvida, o melhor filme adjacente ao Batman desde O Cavaleiro das Trevas. O fator imperdivel do desempenho fascinante de Phoenix sozinho (perturbador e estranhamente comovente) já será significativo ${ }^{19}$.

Há outras análises objetivadas a detalhar ou aprofundar os aspectos psicológicos do personagem, como as fundamentadas, por exemplo, no arquétipo junguiano da "sombra", ou seja, Joker como a manifestação do lado sombria de sua personalidade. Várias resenhas e críticas apresentam pontos de entrada muito interessantes, como por exemplo Jonathan Pageau (2019) sobre como Joker esmaga a narrativa política e Christian Dunker (2019) a respeito das neuropatias nas personagens hollywoodianos a partir de 2010. Aqui, entretanto, objetivou-se refletir sobre possibilidades de significados ocultos (implícitos ou passíveis de interpretação hermenêutica ou simbólica) quando confrontados com os significados aparentes, isto é, as informações e aspectos explícitos do filme. Nesse sentido, fica manifesta a transformação do personagem motivada pelo sentimento de despertencimento, assim como o lugar do riso ao longo da narrativa como explicitação do conflito interior intrínseco ao personagem. Arthur Fleck ria um riso fingido, falso, como subterfúgio para fugir da tragédia (sua mãe afirma que nunca o havia visto chorar, por isso nunca denunciou os abusos do padrasto, e sempre o chama pelo apelido de happy). Porém, teve que admitir a tragédia (sua raiva interior) para conseguir rir verdadeiramente e admirar o caos de sua existência.

\section{Referências}

BRODY, Richard (2019). "Joker" Is a Viewing Experience of Rare, Numbing Emptiness. In: The New Yorker, 03/10/2019. Disponível em: https://www.newyorker.com/culture/the-front-row/jokeris-a-viewing-experience-of-rare-numbing-emptiness [acesso: 10/05/2020].

COËGNARTS, Maarten; KRAVANJA, Peter (2015). Embodied Ethics and Cinema: moral attitudes facilitated by character perception. In: Maarten Coëgnarts and Peter Kravanja (eds.) Embodied Cognition and Cinema. Leuven: Leuven University Press, pp.271-294.

DUNKER, Christian (2019). Desejo em cena: Joker. Disponível em: https://www.youtube.com/watch?v=lohjN6av_Ns [acesso em 10/05/2019]

História dos jogos de carta. Disponível em https://playingcarddecks.com/blogs/all-in/history-playingcards-modern-deck [acessado em: 03/03/2020].

JUNGER, Sebastian (2014). Why veterans miss war? Ted Talks. Disponível em: https://www.ted.com/talks/sebastian_junger_why_veterans_miss_war/transcript

KISS, Miklós (2015). Film Narrative and Embodied Cognition: The Impact of Image Schemas on Narrative Form. In: Maarten Coëgnarts and Peter Kravanja (eds.) Embodied Cognition and Cinema. Leuven: Leuven University Press, pp.43-61.

MOORE, Alan \& BOLlAND, Brian (2008). Batman; The Killing Joke the Deluxe Edition. DC Comics (Original de 1988).

\footnotetext{
${ }^{19}$ Built around a credible spiral from lonely outsider to deranged killer, it's as much a neo-noir psychological character study grounded in urban alienation and styled after Taxi Driver as a rise-of-the-supervillain portrait. It's arguably the best Batman-adjacent movie since The Dark Knight... The must-see factor of Phoenix's riveting performance alone - it's both unsettling and weirdly affecting - will be significant.
} 
PAGEAU, Jonathan (2019). How Joker smashes our political narratives. Disponível em: https://www.youtube.com/watch?v=H74BbcTs6xs [acessado em: 03/03/2020].

ROONEY, David (2019). 'Joker': Film Review. Disponível em: https://www.hollywoodreporter.com/review/joker-review-1235309 [acesso: 10/05/2020].

STRAYER, Chelsea Shields (2013). Why belonging matters. Disponível em:

https://blog.ted.com/fellows-friday-chelsea-shields-strayer/ [acesso em 10/05/2020].

WOOD Jake (2011). A new mission for veterans: disaster relief. Disponível em: https://www.ted.com/talks/jake wood a new mission for_veterans disaster_relief/transcript\#t$\underline{8818}$ [acesso em 10/05/2020]. 